\title{
The recent jurisprudence of the ECJ viewed against the background of the relation between Fundamental Freedoms and Community Fundamental Rights
}

\author{
Robert Rebhahn
}

I. Introduction

II. Fundamental Rights and Freedoms in General 158

III. Recent Decisions and Fundamental Rights $\quad 159$

IV. Assessment and Outlook 161

\section{Introduction}

Many Member States protect collective bargaining and industrial dispute by making them fundamental rights. However, the ECJ has so far never allowed Community law to be subordinated to national fundamental rights since this would threaten unity. In Community law, national fundamental rights as such can only be relevant in so far as they give Member States the possibility of restrictions.

Hence, only Community fundamental rights qualify as a counterweight to fundamental freedoms. To date, the Community has not succeeded in producing a binding catalogue of fundamental rights. Such a catalogue is long overdue since without it, fundamental freedoms continue to occupy the front stage when it comes to fundamental values, both in written primary legislation and in court practice. However, with regard to the enormous increase in competencies and provisions, this is no longer adequate. The ECJ at least recognises unwritten fundamental rights as general principles. However, the absence of any statement on the fundamental right to free collective bargaining in the Albany decision of 1999 is telling in itself. Recently, the decisions in the cases Viking and Laval expressly acknowledge "the right to take collective action including the right to strike as a fundamental right". ${ }^{1}$ This is a major step in its own right, although the

1 cf. on the judgement in the Viking case e.g. Rebhahn, Grundfreiheit vor Arbeitskampf-der Fall Viking, ZESAR 2008, 109-117 
ECJ's reasoning in these specific cases may not be found to be fully convincing from a legal doctrine point of view. An affirmation of this fundamental right of Community law makes it all the more compelling to also affirm free collective bargaining as a similar right. Admittedly, the fundamental right to collective measures does not seem to play a noticeable role in the reasoning of the judgements and the results. For this fundamental right, no legal doctrine has been established by the ECJ to date, either. The - albeit minor - significance that this right does have is fully attributable to court practice as established thus far.

\section{Fundamental Rights and Freedoms in General}

The relationship between fundamental freedoms and fundamental rights of Community law in case of collision is a rather obscure one. It is not so much theoretical propositions that help determine this relationship but rather the ECJ's practice. A judgement may examine interventions in fundamental freedoms or fundamental rights. The few judgements on collisions available to date relate to restrictions of a fundamental freedom. Fundamental rights have featured only as a potential restriction of the fundamental freedom in question. There have hardly been any cases where the ECJ had to examine whether the interference in a Community fundamental right may be justified by the Community or an individual state in the interest of a fundamental freedom. Even in Viking and Laval the issue under review was not whether the right to strike could be restricted on account of a fundamental freedom but rather the contrary. However, the way a problem is presented will always have an impact on perception, which may in turn influence the legal statements that are to be made. If collisions are perceived mostly in the context of a restriction of fundamental freedoms through the exercising of fundamental rights, this may soon lead to an exercising of fundamental rights only "in accordance with the requirements of' fundamental freedoms.

Fundamental freedoms and fundamental rights would be treated on an equal footing only if, in case of a collision, both were assumed to be interests protected under primary legislation which would then have to be "balanced", either on the level which defines the extent of protection or on the level where barriers to intervention are identified. However, this would have to be stated expressly by the court. Decisions taken by the ECJ to date have not visibly reviewed and considered both positions on the same level but have placed fundamental freedoms first. The Schmidberger judgement alone seemed to place both rights on the same level, at least linguistically. ${ }^{2}$ This approximation in ranking is not discernible at all in either Viking or Laval, as the fundamental right to collective action that has just been acknowledged is not brought into play to justify the restriction of the fundamental freedom concerned. At the beginning of the deliberations

2 ECJ of 12/6/2003, Schmidberger, Case C-112/00, Rec. 2003, I-5659. 
on the issue it is indeed stated that the "exercising of the right to collective action" may well be of overriding general interest. However, the judgement does not designate this as a fundamental right. Only protection of working conditions and the EC's social policy are mentioned as concrete examples of general interest, whereas the specific significance of free collective bargaining and industrial dispute - thus, collective representation of interests, by application of pressure if necessary - is being left aside.

\section{Recent Decisions and Fundamental Rights}

The conclusion from Viking and Laval is that at least collective measures targeted against relocation of plants to a different Member State or against the posting of workers are to be measured against freedom of establishment and freedom to provide services. Exercising a Community fundamental right cannot protect trade unions against being subordinated to fundamental freedoms. If that is the case, the exercising of a fundamental right would have to be considered subsequently, which is not done. Even leaving aside the fundamental right, there is arguably no conclusive justification for submitting workers and trade unions to the fundamental freedom concerned. At one point it is being said that it were sufficient for action to be targeted at a normative provision - the collective agreement - whereas later it is being stated that this were irrelevant. A conclusive proposition would be that any factually substantial impairment of a fundamental freedom, also by private entities, leads to a restriction of that freedom which is only admissible if it can be justified. It may well be that the judgements are indeed based on this rather broad proposition - if so, this is not made explicit, however.

Restriction of a fundamental freedom is legitimate only if it can be justified. It is also subject to the imperative of proportionality. Applied to strikes, this criterion amounts to a profound alteration of national fundamental rights for many northern and southern Member States, and for some southern Member States it even means that national fundamental rights are being curtailed. Unfortunately, when it comes to reviewing for proportionality there is, in most cases, no way of telling what the result will be before the judgement is pronounced. This uncertainty places a burden on those wishing to take action, in this case the bearers of fundamental rights. According to the ECJ a justification is conceivable not only for strikes of those employees whose working conditions are at stake, but also for supportive boycotts and thus for sympathetic measures. This, again, is a novelty for some states.

The grounds of justification named in the judgements are protection of employees, and, in more concrete terms, the aims of EC social policy. The fundamental freedom is to be balanced against these aims. It seems, however, that, in accordance with the Viking judgement, a strike can only be justified if jobs or working conditions are in danger or under serious threat, which is a narrower definition than found in many national fun- 
damental rights, and this appears to be the case not only for strikes related to social policy legislation. It probably is a novelty in Community law that the ECJ accepts interests that are primarily economic in nature for justification in this case. However, this does not compensate for the fundamental right being eclipsed at least verbally.

Even if there is a danger or a threat, the national court must review whether the measure is suitable and necessary to ensure attainment of the objective. Presumably, the imperative of necessity is to be neglected if national law offers other means to attain a collective agreement, which restrict the freedom of establishment to a lesser extent. This could lead to the conclusion that the parties are to submit themselves to voluntary arbitration first, which would, again, mean stricter limits than those set out in national fundamental rights. Moreover, the Viking decision states that the enterprise whose fundamental freedom is being infringed may confer rights against trade unions from this. In some countries, this will, for the first time ever, necessitate effective sanctions against strikes. The fact that the persons acting are bearers of fundamental rights is hardly expressed in the judgement.

The decisions in Laval and Rüffert relate to the posting of workers, thus putting the Posting Directive in the foreground. The Laval judgement is the first to expressly state in this context that the Directive exclusively regulates the possibilities of the state of work to make its labour law compulsory for posted workers. I was and still am of the opinion that this interpretation is easily justifiable on account of the competence for the internal market claimed by the EC. However, it is not compelling and some more justification would have been necessary. It is at any rate doubtful how this relates to employees' fundamental rights.

In Laval, the matter under review was not a strike of posted workers but a blockade of Swedish workers against posting, since the Swedes considered their working conditions to be in danger. In essence, the judgement places this boycott, which is more than an industrial struggle out of sympathy, into the sphere of protection of the fundamental right as well. This is a novelty for many Member States. At this point, at the very latest, it becomes apparent that the decision (also) neglects entrepreneurial interests other than the fundamental freedoms, which may be arguments against a boycott. The conflict of interest between boycotters and posted employees is not expressly mentioned either.

The ECJ, in any case, restricts its review of whether the boycott is admissible to the Posting Directive. However, Sweden did not make use of all possibilities offered by the Directive as it has not prescribed for posting companies also those collective agreements which are not generally binding but are indeed generally applicable. In accordance with the judgement it is at any rate inadmissible for the national peace obligation to be triggered by national collective agreements alone since this would amount to unequal treatment of foreign collective agreements. It is also inadmissible to impose an obligation on posting companies to negotiate minimum wages with trade unions first.

The judgement appears to be coherent. However, certain doubts arise upon closer scrutiny. The Posting Directive itself relies on the principle that foreign collective 
agreements and national collective agreements will not always be treated equally. Moreover, the judgement assumes that free collective bargaining and industrial dispute are guaranteed only in accordance with the requirements set out in the Posting Directive. However, the question could have been asked and indeed should have been asked whether Community fundamental rights to collective measures and free collective bargaining are sufficiently considered in the Posting Directive, in particular taking into account that, according to the prevailing opinion, the Community is not allowed to regulate the collective bargaining system. The judgement does not specifically mention protection of national collective bargaining systems as a justification for the restriction but essentially leaves the issue aside.

The Rüffert judgement relates to a law on compliance with collective agreements. The requirements of the law in question go beyond those of the Posting Directive. The ECJ finds this to be in contradiction with the freedom to provide services, in particular because it were not clear why a posted worker would require stronger protection when working for a public employer. Apparently, this is to say that this distinction does not constitute a factual justification. This kind of "consideration" may well be used to question all labour legislation provisions which assign more duties exclusively to certain entities - such as the state - when they act as an employer or customer, as is the case for example in anti-discrimination law. Moreover, the Rüffert decision also fails to deliberate whether the law requiring compliance with collective agreements serves the purpose of collective bargaining and thus a Community fundamental right. The German Federal Constitutional Court, in contrast, explained in justifying the law on compliance with collective agreements against freedom of occupation that this kind of legislation supported the regulatory function of collective agreements and the right to free collective bargaining as a protected fundamental right. The ECJ has not reacted to this, despite the much-praised dialogue with national supreme courts. The need to deal with this is not rendered obsolete, either, by claiming that the Federal Constitutional Court's concern was to protect the national right to collective bargaining. After all, a Community fundamental right to collective bargaining could also encompass protection of the different options existing nationally.

\section{Assessment and Outlook}

From a labour law point of view, it is conspicuous that the judgements referred to do not treat collective action and collective agreements as a regulatory problem and as institutions of working life but as marginal phenomena of the internal market. There is no discernible effort to deliberate in how far collective arrangements and actions may be reasonable or necessary in either abstract or concrete terms on account of an asserted imbalance in the labour market. These phenomena are seen as mere disturbances in the 
exchange of services. This seems to be a simplistic view of things which may explain why blockades are simply treated in the same way as strikes for peoples' own working conditions, meaning that employers' interests other than the fundamental freedoms are ignored.

Neither is the following contradiction taken into account: Community law restricts only actions by employees in situations created by the internal market. These actions often function as a surrogate for the lack of a secure legal framework for collective agreements and strikes across internal borders, not least because the Community is not authorised to regulate strikes and may not be authorised to regulate collective agreements either. However, for as long as the Community fails to regulate these areas it should exercise constraint in restricting national possibilities.

Measured against traditional standards of not only legal doctrine but also general requirements with regard to statement of reasons, the deliberations on the relationship between fundamental freedoms and fundamental rights in Viking and Laval are little convincing. The ECJ's attention and concern is focused exclusively on the fundamental freedom in question whereas other aspects are relegated to the fringe and all possible arguments are used in favour of the fundamental freedom. This broad understanding of fundamental freedoms does indeed correspond to the phrase of effet utile. However, with regard to Community fundamental rights a similar eagerness for effet utile seems to be missing, unless even the acknowledgement of unwritten Community fundamental rights were to be seen as an expression of this principle of interpretation. Fundamental freedoms rank higher than fundamental rights up until this day, at least in terms of their effect. The ECJ can thus hardly be considered a guardian of fundamental rights. This is barely desirable for as much as it may be inherent to existing positive law.

A subordination of fundamental rights to fundamental freedoms also becomes apparent when the problem is transposed to national constitutional law. Freedom of establishment and freedom to provide services are material forms of entrepreneurial freedom. No normal state would consistently favour certain entrepreneurial rights above fundamental rights simply because they affect action that goes beyond internal borders. Why, then, should an organisation that does not even aspire to be a state do it?

This paper will leave aside the question whether the ECJ would come to the same conclusions of its judgements if all missing aspects that have been indicated were to be included. However, a comprehensive reasoning would have to make obvious the merit of the ECJ taking seriously the problems that affect many people in the Member States. Moreover, this would also make it easier to accept the results even for those who do not wish them to turn out exactly as they do for reasons of legal policy in the first place. Justice should not only be done, but should manifestly be seen to be done.

European law experts admittedly claim that the ECJ's decisions should not be measured by traditional standards. It is said that no mere legal doctrine or even orientation towards the intentions of the legislature should be expected, but that, apart from the legal surface, the deep structure should be considered and law should be perceived within 
its political context. These recent decisions clearly favour competition with low labour costs, also across borders, thereby benefiting certain Member States. This effect is inherent in the Posting Directive in particular, if understood in the same way as done by the ECJ. However, this is not a compelling interpretation. The fact that after enlargement twelve new Member States are now represented, also in the ECJ, may thus be relevant for a better understanding of these decisions. The majority of these states will expect Community law to support their competitive position, at least where postings are concerned, now that they are after all requested to open up to an inflow of capital, goods and managers. Observers will therefore claim that these decisions tie in with the expectations of these countries and thus promote integration and that the ECJ would thus be seen to promote integration and the internal market, even at the expense of traditional workers' rights. Acknowledgement of a fundamental right void of concrete consequences then seems to be a means of increasing acceptance.

The primacy of context before legal doctrine raises questions about the role of the ECJ. At a time when political integration and legislative action stalled the ECJ was hailed as a motor of integration. However, for a number of years now there can be no talk of constraint in Community legislation. The question is whether the ECJ should continue to focus its efforts on promoting integration through its decisions even if that promotion does not result from a compelling inference. If it continues to drive integration regardless, there is a danger that it will no longer be perceived as a guarantor of law but as a "courageous" actor in politics. As a court, the ECJ would be in a position to reduce the reservations against European policy maintained by many citizens of the Union. When acting primarily as a political player, however, it will only increase these concerns. In doing so, it will reduce trust and confidence among a substantial share of the EU population rather than building it.

\section{Übersetzung: Nele Faßnacht}


